\title{
Article \\ Shall We Dance? Defining Sexuality and Controlling the Body in Contemporary Indonesia
}

\author{
Okky Madasari
}

check for updates

Citation: Madasari, Okky. 2021. Shall We Dance? Defining Sexuality and Controlling the Body in Contemporary Indonesia. Religions 12: 264. https://doi.org/10.3390/ rel12040264

\section{Academic Editors:}

Maznah Mohamad and Terry Lovat

Received: 8 March 2021

Accepted: 7 April 2021

Published: 9 April 2021

Publisher's Note: MDPI stays neutral with regard to jurisdictional claims in published maps and institutional affiliations.

Copyright: (C) 2021 by the author. Licensee MDPI, Basel, Switzerland. This article is an open access article distributed under the terms and conditions of the Creative Commons Attribution (CC BY) license (https:// creativecommons.org/licenses/by/ $4.0 /)$.
Department of Malay Studies, National University of Singapore, Singapore 119077, Singapore; e0437688@u.nus.edu

\begin{abstract}
This article examines how Indonesia, the world's third-largest democracy, came to define sexuality for its general population once intimacy was brought into the public sphere. However, its Islamic version had predominantly been based on interpretations pushed by politically hardline Islamist groups. The influence of this lobby (to be referred to as belonging to the stream of 'conservative Islam') grew steadily after the downfall of the Suharto regime in 1998 and culminated in the passage of an antipornography law ten years later. Focusing on the definitions of sexuality and pornography forwarded by these groups, this article analyses their limitations as well as the power contestations behind the passage of the antipornography legislation. It argues that such narrow interpretations of sexuality have had a marked impact on the nation, in particular the curtailment of its popular culture and creative industry. This has resulted in the arbitrary persecution and banning of cultural products considered to violate Islamic morality and propriety. The condemnation of dangdut singer Inul Daratista, and her 'drill dance', is one of many examples of such suppression.
\end{abstract}

Keywords: pornography law; intimacy; sexuality; Islam; popular culture

\section{Introduction}

Homosexuality is not illegal in Indonesia, except in Aceh, which has applied strict sharia laws since 2001. However, homophobia is prevalently etched in the minds of many Indonesians today. For instance, as recently as January 2021, Indonesia gained worldwide infamy when it deported an American lesbian couple from Bali after their tweets about the "queer friendly" resort island went viral. An Indonesian official subsequently said that the couple was sent back to the US because they were suspected of having intentionally disseminated "unsettling information" about Bali. ${ }^{1}$

For the majority of Muslims in contemporary Indonesia, being seen as sympathetic to homosexuality can be very unpleasant and dangerous. This is especially so for state officials; they have to quickly reject such a claim to save their job and, more importantly, prevent public anger and demonstrations against their office. ${ }^{2}$ Such episodes are hardly unique now and can happen anywhere across the archipelago, highlighting the monopoly of heteronormativity, discrimination against homosexuals, and the state of sexuality in general in an increasingly authoritarian Islamist Indonesia.

Islam's pivotal status in the country reflects its overwhelming majority Muslim population. ${ }^{3}$ With an almost 90 percent Muslim populace, one cannot escape Islam permeating almost every facet of life-from politics to the economy to culture-despite the deliberate push toward secularism since independence in 1945. To say Islam has a role in Indonesia's

1 See Paddock (2021) and Cahya (2021).

2 Special reports by Human Right Watch, "Scared in Public and Now No Privacy": Human Rights and Public Health Impacts of Indonesia's Anti-LGBT Moral Panic, July 2018 (see Human Right Watch 2018), and the report from Kompas, (see Erdianto 2016).

3 According to the World Population Review, in 2020, Muslims in Indonesia constituted 87.2 percent of the country's total population, or 229 million of its 263 million people, making it the world's largest Muslim nation, with 13 percent of the global Muslim population (see The World Population Review 2021). 
development and political life is an understatement. Regardless of the interpretation of its teachings, Islam has shaped the nation since its formation to the present and will do so as long as it continues to exist.

As an electoral democracy, numbers matter most. It is thus expected that Islam hasand that Islamic groups will assert-some level of authority and influence in the country's social, economic, and political fields ${ }^{4}$. In politics, for instance, while a single party aligning with Islam has never won the elections by itself, together they garnered the highest number of votes in every election since the first in 1955, except during Suharto's New Order Era when everything was arranged to make sure that the Golkar Party dominated the elections. In the 2019 election, all of these parties explicitly considered themselves to be aligned with Islam - the National Awakening Party (PKB), the Prosperous Justice Party (PKS), the National Mandate Party (PAN), the United Development Party (PPP), and the Crescent Star Party (PBB) - and they garnered more than 30 percent of the total vote, far more than the election winner, the Indonesian Democratic Party of Struggle (PDI-P) with over 19 percent (Farisa 2019). It should also be mentioned that two of Indonesia's major nationalist parties-Prabowo Subianto's the Great Indonesia Movement Party (Gerindra) and former president Susilo Bambang Yudhoyono's Democratic Party (Partai Democrat) — have been specifically wooing Muslim voters and have huge numbers of Muslim followers. These two parties, plus the other five Muslim-aligning parties, have made up more than 50 percent of the total popular vote. These facts help explain the nature of the power contestation at the House of Representatives (DPR) when lawmakers reviewed bills, including the case of the antipornography bill. It is against this backdrop that the question of who represents Islam and the Muslim community (ummah) becomes crucial, because actors or groups perceived as defending the interests of the ummah will determine the public face of Indonesia's Islam. The country's politically Islamist groups have stepped up to assume the role of speaking and acting on behalf of Islam, seizing the leadership vacuum, as moderate factions within Nahdlatul Ulama (NU) and Muhammadiyah ${ }^{5}$ have seemingly not expressed interest in playing the leading role. The result of this is that Islam in Indonesia has been monopolized by the character of conservatism throughout the first two decades of the 21st century (Sebastian et al. 2021, p. 7).

Indonesia began moving towards democratisation after freeing itself from 32 years of repression under the Suharto New Order regime and integrating itself into the globalised world. As noted by Brenner (2011), the fall of Suharto in 1998 allowed for major changes to take place, namely, the shift toward open elections in the political arena, the deregulation and expansion of the mass media, far greater freedom of speech and protest, the decentralization of government, and insistent calls for improved government transparency and accountability (p. 478).

With global economic interests pressing for Southeast Asia's biggest economy to open up its market, and international civil society groups advocating for human rights to be upheld within the archipelago, many among the Indonesian urban middle class have actively supported more liberal causes. The rise of enhanced communications technology and social media have also seen a large part of its society seeking more individual freedoms, including the right to express themselves politically, socially, and sexually. Using social media to make their voices heard is also an attempt to check the ever-growing influence of conservatism as propounded by Islamist groups in the nation.

\section{Materials and Method}

This article looks at the 'experiment' or testing out by Indonesia's politically Islamist groups, to be referred to as belonging within 'conservative' Islam, in comparison to other

4 Reports by Reuters on Indonesia's economy (see Suroyo and Diela 2019), The New York Times on politics and lifestyle (see Beech and Suhartono 2019), and Nikkei on public policy (See Jibiki 2020).

5 Scholars have differed on how many members NU or Muhammadiyah has. However, they agree that both are Indonesia's two largest Muslim organizations. Fealy (2018) mentions that NU claims to have around 40-45 million members, while Muhammadiyah has around half of NU's members. 
more democratic religious orientations. Their 'experiment' was to push for a homogenous definition of sexuality, ending with their success in having a controversial antipornography bill passed into law in 2008. Besides tracing how intimacy had been brought into the public sphere in order to define sexuality, this article discusses how the body is controlled through discourses and practices in the passage of the controversial law. Of particular impact is its curb on creativity in pop culture within the fields of music and the performing arts.

The analysis utilises the framework of the two major competing forces-the Islamist movement versus democratisation-as the context and analytical tool to explain efforts by state and nonstate politically hardline actors to define sexuality for Indonesians and to show how such a definition affects the country's democracy, as well as its creative industry and popular culture. The article's socio-historical approach analyses current data in the form of policy and legal outputs, state documents, official and private statements, and news stories published by news outlets, as well as books and journals, to explain the motivations and causes behind such outputs. This article questions why Indonesia was able to have such a pornography law and examines the impacts of the law on people's views and actions on sexuality and on the creative industry when the law's definition of sexuality was followed and acted upon. The article tracks the origin of the law and the actors behind the passage of the bill. The article will not characterize or stamp essentialist values or concept to any political party based on popular perceptions but will denote them only by their actions and policy outputs in accordance with available concepts used in scholarly global literature. Hence, the article will characterize PKS as a conservative or Islamist party, not because they have certain conservative values, but based on their actions in supporting and fighting for policies and laws supporting exclusivity while curbing freedom and democracy, as in the case of the passage of the antipornography bill into law. Similarly, the article considers the Indonesian Ulama Council (MUI) as becoming increasingly conservative and Islamist because of its actions, e.g., championing the banning of Ahmadis by issuing an edict (fatwa). MUI has also advised Muslims against wishing their Christian friends a merry Christmas.

This article relies on secondary sources and literature analysis. To support the argumentation put forward here, this article digs into relevant past and current news reports published both by Indonesia's media and international news outlets, which include data, information, and storylines about the issues, interviews of, and statements from actors involved in the matter. Likely influences on the narratives can be gathered and analysed. This article also borrows and immensely benefits from the previously published works of scholars and academics who have studied Islam, sexuality, and democracy in Indonesia.

The analysis begins with an exploration of evidence that this form of Islamic conservatism arose and assumed control in Indonesia following the fall of Suharto. This includes examining how and why this could have taken root and highlighting the trajectory of Islamic movements in the country's post-Suharto rule. The next section of the article addresses the question of why politically Islamist groups have sought to regulate private life by focusing their efforts on controlling the body through the promotion of a restrictive definition of sexuality.

In explaining how this lobby had pushed for such regulation, this article also demonstrates why and how competing groups responded to these efforts. The dynamism of moves and countermoves will be illustrated through a case study of the highly controversial antipornography law. The last section will show how the definition of sexuality imposed by conservative groups has impacted Indonesia's popular culture. It discusses the controversy surrounding Inul Daratista's 'drill' dance and the closure of Playboy Indonesia, so as to better illustrate how such a definition has curtailed the development of creativity and cultural and artistic products in the country. 


\section{The Rise of Political Islamism in the Form of Islamic Conservatism}

Scholars who have studied Indonesia closely generally agree that political Islamism is popularly associated with the rise of Islamic conservatism, although the latter label may not truly reflect an older, precolonial Islam that was prevalent in the country. Nevertheless, when compared to the flourishing of democracy post-Suharto, a seeming reaction to liberalism can be experienced as the heralding of a "conservative turn".

The conservative turn reflects the shifting face of Indonesian Islam from a more

liberal, tolerant and open-minded discourse in Islam toward a more intolerant, extreme understanding of Islam and the desire for Muslims to live under Islamic law. (Sebastian et al. 2021, p. 6)

For Sebastian et al. (2021), conservative groups are those that reject interpretations of the Islamic doctrine as $b i^{\prime} d a$ (human innovation). They conclude that fundamentalist readings of how Islam should be practised is the main reason for the increasing incompatibility between Islamic conservatism and multireligious Indonesia. At the heart of the "conservative turn" are a number of influential groups. Besides the Front Pembela Islam (FPI, Islamic Defenders Front), these include Majelis Ulama Indonesia (MUI, Indonesian Ulama Council), NU Garis Lurus, Majelis Mujahideen Indonesia (MMI, Indonesian Mujahideen Council), Hizbut Tahrir Indonesia, Gerakan Nasional Pengawal Fatwa-Ulama, and Islamic political parties like Partai Keadilan Sejahtera (PKS, Prosperous Justice Party).

The growth in Islamic conservatism has translated into concrete, visible consequences in the national agenda and in policymaking, wherein politicians increasingly utilise religious rhetoric in their arguments. They are well aware that being perceived as insufficiently pious can be a serious disadvantage in Indonesian politics today, especially as Islamic organisations possess one of the most reliable vote-canvassing machineries in the country (Sebastian et al. 2021).

For example, in late July 2020, Joko Widodo's Minister of Education and Culture, Nadiem Makarim, was forced to issue a public apology to NU and Muhammadiyah, the country's two largest Islamic organisations, for sidelining them in a teachers' training programme under his ministry (Nikkei, 18 August 2020). ${ }^{6}$ While broadly known for being moderate Muslim bodies, NU and Muhammadiyah have become more reactionary over time as their respective conservative factions have gradually gained influence (Sebastian et al. 2021).

Under the authoritarian regime of Suharto-Indonesia's second president, who came to power in 1968 - the government suppressed the political influence of Islam, fearing that united Muslims and Islamic organisations would move towards fundamentalism and radicalism and then challenge his grip on power. As Indonesia began to democratise itself after Suharto was ousted, the military's power was checked by the acceptance and practice of more democratic norms among the people. With greater freedoms available, Muslim organisations, a number of which were conservative, began to flex their muscles and promote their agenda in the country's political, business, social, and cultural realms.

Today, it has become almost routine to read about cases and incidents where Islamic conservative groups have imposed their will on others. For instance, in February 2020, Indonesia's broadcasting authority issued a warning to a TV station that screened a programme featuring wine made in Bali, on grounds that since alcohol is considered 'haram' (forbidden) in Islam, the programme was offensive to Muslims (Nikkei, 18 August 2020). In many areas across the archipelago, small Muslim groups have taken the law into their own hands, for instance, by attacking churches and forcing the construction of churches to be halted (Setara Institute for Democracy and Peace 2019), and by raiding bars and cafes to find alcoholic drinks (BBC Indonesia, 25 May 2017).

\footnotetext{
6 Nadiem, a businessman and founder of the ride-hailing giant Gojek, initiated a programme wherein teachers would be trained by private sector bodies. NU and Muhammadiyah rejected the idea of engaging already-rich companies and remunerating them with taxpayers' money. Nadiem overhauled the programme based on their inputs, showing how Muslim interests have become fused in national policy.
} 
Perhaps an example that best reflects the rising influence and role of Islam and Islamic organisations in Indonesian social and political life is the incident that transpired as the 212 Movement. On 2 December 2016, conservative Islamic groups organised a rally against Basuki Tjahaja Purnama (Ahok), then the Governor of Jakarta and a close ally of President Jokowi, whom they accused of having committed blasphemy against Islam and the ulama (Islamic clerics). The rally, which resulted in Ahok being toppled and later jailed, is claimed by some as the largest demonstration in the country's history (Jakarta Globe, 17 April 2018).

Whether there were several hundreds of thousands or more than seven million protestors, the crowd was very large and showed the capacity and force of the conservative lobby in dictating their will in public and political affairs. As the culmination of the growing appeal of conservative groups since they emerged out of Suharto's shadow, the demonstration not only profoundly changed the way in which the role of Islam and Islamic organisations in political and social affairs of the country was viewed but also revealed a surprising fact, namely how much support these groups had among the Indonesian public. This rally changed Joko Widodo's political approach towards these conservative groups, for instance, in his pick of his running-mate ahead of the 2019 presidential election to woo Muslim voters. Instead of picking Mahfud MD, a moderate Muslim scholar, he chose conservative cleric Ma'ruf Amin, proponent of the 212 rally. Amin's rise to become Jokowi's vice president has further allowed conservative groups to have a strong hold on the nation's direction.

\section{Conservatism Moves in to Regulate Sexuality}

The fall of Suharto brought freedom to Indonesia. Among the changes witnessed in the years that followed were political reform, democratisation, and the protection of human rights. Indonesia moved to hold open and direct elections at the national and regional levels, deregulate and expand the mass media, give greater freedom of speech and expression, and decentralise government. However, all this also created two major competing currents that became a source of tension in the more than two decades that followed the dismantling of totalitarian rule.

In the early years of Reformasi, a movement of political and social reform, Indonesia undertook a number of measures and initiatives that reflected the new administration's seriousness in distancing itself from the regime that had been toppled. There was an overhaul in governance, including in the areas of gender equality and the protection of women and children. For example, the establishment of Komnas Perempuan (National Commission on Violence Against Women) was seen as a serious effort in handling the May 1998 tragedy, the mass rape of Chinese Indonesian women on the eve of Suharto's downfall (Platt et al. 2018).

In 2006, Indonesia signed on to the Yogyakarta Principles on the Application of International Human Rights Law in Relation to Sexual Orientation and Gender Identity. This move was welcomed by some quarters as a sign of potentially greater inclusivity of nonheteronormative orientations and identities into Indonesia's social fabric. As Platt et al. (2018) underlined, Indonesia's commitment to upholding the basic human rights of all citizens regardless of gender or sexual orientation placed the nation among its peers in Asia who call for the recognition of sexual freedom and represented a progressive widening of moral possibilities with regards to sexuality.

Subsequently, Komnas Perempuan and Komnas HAM (National Commission on Human Rights) worked together with LGBT (lesbian, gay, bisexual, and transgender) organisations to promote the human rights of all Indonesian citizens. The former, for instance, started by recognising lesbians, bisexual women, and transwomen as part of the mandate of Komnas Perempuan. This was remarkable given that at the global level transwomen had been - and continue to be-excluded by many women's organisations (Platt et al. 2018).

Progressive organisations were not the only ones who used democracy to make their presence felt. In the realm of religion, freedom of expression gave space for both more 
inclusive and more conservative voices to be heard. As mentioned earlier, having been heavily suppressed under Suharto's New Order regime, there was a dramatic growth of interest in the study and practice of Islam in the new era. Conservative religious groups emerged during this time. ${ }^{7}$

With more freedom after Suharto, this movement expanded exponentially, capitalising on democratic means to gain influence and exercise power. This renewed spirit of Islamisation has been felt in virtually all spheres of life today, from the economic and political spheres to matters relating to social and cultural life. For example, there has been an increase in modes of piety with more women wearing the hijab (headscarf) ${ }^{8}$ and in the introduction of sharia into regional regulations and by-laws (BBC Indonesia, 15 August 2019).

As Islam in general and conservative Islamic groups in particular gained ground postSuharto, it was just a matter of time before they asserted themselves in the realm of morality, freedom of expression, creativity, and private life, especially the sexuality and sexual life of citizens. Even so, Islamic conservatism's foray into matters to do with sexuality also needs to be weighed against the presence of other actors. Aside from conservative Islamic variants, there is liberal or civil Islam, a brand of Islam which is moderate, tolerant, and inclusive, rooted in the country's long-held values of civic discourse and associationRobert Hefner popularized the term in 2010 while pointing to NU as an example of civil Islam (Sebastian et al. 2021). Within democratic society, there are human rights activists and groups, as well as mass and social media, all with varying degrees of influence over Muslims.

Previously, efforts to bring down Suharto and his military regime were perceived as a fight to sweep away an immoral and corrupt regime. The ensuing Reformasi witnessed a struggle to bring back 'good' morality to the nation (see Platt et al. 2018; Brenner 2011), where the hero and saviour of the nation was projected to be those with 'good' morality and hence, who are able to 'save' the nation from the same fate as before.

It is at this juncture that conflict arose: What is good morality? What constitutes a morally good person? This is the 'battle' that defines postauthoritarian Indonesia, wherein each competing group is out to proclaim itself as the moral authority. Further, given its predominantly Muslim populace, the Islamic definition of morality prevails as the standard for the entire nation. Since Muslims also consider sexuality a very important aspect of morality, a lot of attention has been directed to its expressions and practices. The female body in particular has been a key battleground in which contests over democratisation, as well as Islamic morality, are waged (Brenner 2011).

The rewards for dictating the meaning of sexuality, including winning symbolic dominance over public morality, explains why conservative groups took significant actions to lead public discourse on these issues from the start of Reformasi. They have taken measures to bring social and economic activities in line with their definition of Islamic morality and sexuality as well. For them, defining sexuality has a lot to do with controlling the private life of Muslims, and it is this power they hold on to rather than over morality itself.

\subsection{Conflicting Views and Definitions of Sexuality}

There are a number of ways to understand the term 'sexuality'. This article takes the definition of the World Health Organization (WHO), given its recognition as a global authority. This describes sexuality as "a central aspect of being human throughout life and encompasses sex, gender identities and roles, sexual orientation, eroticism, pleasure, intimacy and reproduction. Sexuality is experienced and expressed in thoughts, fantasies, desires, beliefs, attitudes, values, behaviours, practices, roles and relationships" (World

7 It is worth mentioning that, although they kept a low profile under Suharto, Islam was still able to quietly expand in schools, universities, and the private and public realms in the 1980s and 1990s, inspired by the new spirit of religiosity across the Islamic world (Brenner 2011).

8 According to an article in The Conversation (see Qibtiyah 2019), out of 626 Indonesian Muslim women asked in 2014, some 64 percent said they had worn it, and only 4.31 percent said they would not wear it, with the rest saying they were still thinking about it. 
Health Organization 2002, p. 5). This United Nations body further elaborates that while "sexuality can include all of these dimensions, not all of them are always experienced or expressed, and that sexuality is influenced by the interaction of biological, psychological, social, economic, political, cultural, ethical, legal, historical, religious and spiritual factors." (World Health Organization 2002, p. 5).

If sexuality is acknowledged as a central aspect of "being human throughout life", and human rights are accepted as universal and inalienable, it follows that the right to sexuality, including bodily autonomy and integrity, belongs to every person. Put simply, sexuality is a basic right of every human being.

In Islam, there is no agreement on a comprehensive definition of sexuality. Most scholars who have reviewed this subject within Islam only address certain components of sexuality and limit their explanations to these, for instance, the right way to have sexual intercourse, marriage as a vehicle for halal sex, sex in marriage, and haram (forbidden) sexual relations, whether these are extramarital or same-sex intercourse. While these occur in the private realm, they are increasingly regulated in the name of Islam (Dialmy 2010). While Davies (2019) acknowledges that Islam is actually one of the most positive of all world religions when it comes to sexuality and marriage, including acknowledging women's right to divorce and necessitating women's consent before sex, she argues that political interests, influence of local culture, and different interpretations of the Hadith and Qur'an from different clerics lead to conflicting opinions on sexuality.

Dialmy (2010) argues that sexual standards in Islam are paradoxical. Having sex is permissible and even encouraged. On the other hand, there is discrimination between male and female sexuality, between marital and nonmarital sexuality, and between heterosexuality and homosexuality. His explanation of what dominant Islam views as characteristics of sexuality, sexual relations, and marriage is useful to provide greater clarity on these matters. The list below is a summary of Dialmy's view on sexuality in Islam (Dialmy 2010, pp. 161-65). They are by no means complete or exhaustive, but they can illustrate the general principles of women's sexuality ascribed to Islam.

1. There must be no sexual relations outside of marriage (nikah). Such acts are regarded as zina (unlawful sexual intercourse) and one of the biggest sins in Islam. There are many treatises detailing how to conduct sexual intercourse with the blessing of God. The Prophet Muhammad, for instance, says that "None of you must throw himself on his wife like an animal." (Dialmy 2010, p. 161). According to Dialmy, the Prophet emphasised the benefits of 'preliminaries' before sex-glances, fine words, caresses, kisses, games etc.-in his teachings. Following his example, Muslim clerics recommend that men should not climax before their wives, and that the husband must take into account the rights of his wife during coitus.

2. Marriage is a male-dominated affair. From the beginning, it is the man who has the authority to choose his wife, and to marry up to four wives in case of the illness, infertility, or aging of an existing spouse. Marriage is a way of maintaining men's interests. Because men are believed to be sexually active for life, polygyny is said to keep them from committing adultery. Muslim men are allowed to marry women from different religions, such as Judaism and Christianity, but women are legally prohibited from doing so.

3. A Muslim woman's worth is judged through her obedience, service, and loyalty to her husband, and how many children, especially boys, she can produce. Men are respected if they have many children, while a couple without offspring is often ridiculed. Such thinking is based on the belief that a family with many children (sons) will be strong as their children will provide economic and political stability.

4. In the past, men had the right to own an unlimited number of sex slaves (concubines). Women could also own slaves, but they were not allowed to have sexual intercourse with them. They could only have sex within marriage. In current times, the practice of possessing sex slaves is legally prohibited even though some argue that the Qur'an still allows this for men. 
5. The notion that virginity is a virtue for women allows men to control the female body and sexuality. This stems from a fear that if a woman has surrendered her virginity to another man, she will have sentimental allegiances to this former partner. Instead, it should be a husband who is his wife's first teacher about sex. He must also be the one who takes the initiative in their sexual relations, where the missionary position is upheld as the norm since this is the optimal position that will allow her to quickly conceive. Based on this logic, Islam is said to prohibit sodomy, with some hadith attesting (Dialmy 2010, p. 162): (1) "Who takes a woman from behind is cursed", (2) "Sodomy of women is illicit", (3) "Who takes a woman from behind is not seen by God on Judgment Day", and (4) "Sodomy of the wife is equal to minor homosexuality".

6. A wife's right to orgasms is acknowledged, but not because she is entitled to them or because they will make her happy. Instead, it is due to a fear that, if she is not satisfied, she will be unfaithful. Orgasms are thus seen as fundamental to a wife's fidelity.

7. Men's control of women's bodies is required to maintain social order. Underlying this is another fear: that uncontrolled female sexuality will lead to social chaos.

8. Islam upholds heteronormativity and is biased towards heterosexuality. Most clerics reject homosexuality outright. The Qur'an itself does not specify a legal sanction against homosexual activity. This has caused Islamic jurists to hold divergent views on sanctions for homosexuals. In many Muslim countries, however, homosexuals are imprisoned, whipped, or sentenced to death.

The eight viewpoints of Islam above are clearly in conflict with the WHO definition of sexuality. While the WHO regards sexuality rights as an integral part of human rights, for men and women alike, the Islamic view is very male-centred and patriarchal. This view puts women as subservient to men and is very suspicious of women being 'evil' if not under male control. Also, there appears to be little room within Islam to accept homosexuality, while the WHO recognises every individual's right to determine their own sexuality, including their sexual and gender identities.

There have been some articles that challenge this majority opinion by stressing the importance of looking at an individual level rather than focusing only on meso and macro levels, such as organizational and societal levels. In an editorial introduction to 'Islam and Sexuality: Orthodoxy and Contestation,' Yip argues that this approach "enables us to appreciate the complementarity as well as contradictions of these levels, which give rise to various forms of contestation and accommodation which, though messy and even inconsistent, offer us a more accurate picture of how religion is lived." (Yip 2009). He describes how women and homosexuals in several countries have found their own way, space, and resources to express sexual pleasure and agency despite limitations and burdens put on them by patriarchal and religious structures.

While these arguments are valid and very useful in trying to portray the realities of how Muslims actually live their sexuality, this description is irrelevant to groups that have pushed conservative agendas, such as the passage of the antipornography law in Indonesia, as this does not apply to them. These groups use the orthodox definition of sexuality and are in unity when it comes to pushing their agenda into action. Outside of these political groups, the general public in Indonesia is also equally orthodox and conservative, especially when it comes to homosexuality, as reflected by a series of surveys in recent years. A survey by Saiful Mujani Research and Consulting (SMRC) on 1220 respondents across the country in 2016-2017, for instance, found that 87.6 percent of those surveyed considered lesbians, gays, bisexuals, and transgenders (LGBT) to be a threat, beyond merely disapproving of them (Sani 2018). Meanwhile, United States-based Pew Research Institute, which polled 38,426 respondents across 34 countries from May to October 2019, found that 91 percent of Indonesians believe that homosexuality cannot be accepted by society (Adjie 2020). 


\subsection{Sexuality Defined for Indonesian Muslims}

The points outlined above broadly sum up what sharia law says about gender, family and sexuality. The same principles have been applied in Indonesia, for instance, in the country's antipornography and sharia-based laws at the regional level.

As noted above, in the nation's quest to remedy the consequences of the immoral New Order regime, different groups within the Muslim community and Indonesian society as a whole have been challenging each other to be the rightful 'champion' of good morality. Those who can achieve this goal will be seen as the 'saviour' of the nation, and in turn, have extensive influence and control.

In pushing for their definition of morality and sexuality, conservative Indonesian groups have promoted the adoption of sharia law and codes for regulating behaviour, specifically the way women dress and move in public. Concurrently, they have pressed for restrictions on materials and actions considered 'pornographic', as well as pursued efforts to stop the government from intervening in family matters, such as the practice of polygamy, which many conservative Muslims believe should be governed by Islam rather than the state (Brenner 2011).

Saskia Wieringa (2015) has argued that the government and its agencies have, by design, supported the Islamic conservative concepts of sexuality, gender, and family. In so doing, they have preserved patriarchy, suppressed women's rights, and perpetuated violence against women. To illustrate her point, she singles out the deployment of a programme, Keluarga Sakinah (Happy Family), actively promoted by the Indonesian Ministry of Women's Empowerment and Children Protection to reduce domestic violence.

Wieringa's analysis shows that instead of its stated aim, the programme was a front to reintroduce heteronormativity in Indonesia, a country which for a time fully-albeit briefly-embraced the discourse of women's rights, and where homosexuality was never banned. In fact, the Keluarga Sakinah programme, like other government gender harmony programmes, sought to restrict the rights of women as well as that of LGBT communities. More important perhaps, "it covers up the epistemic violence against women and LGBT persons that is pervasive in state institutions and public discourse, and adversely affects the psyches of individuals." (Wieringa 2015, p. 28).

The Keluarga Sakinah programme was one of many state-sponsored programmes that promoted the teachings of conservative Islam. At the regional level-in regencies and provinces-many of the hundreds of by-laws that were issued impose conservative behavioural and dress codes on women, and some criminalise homosexuality.

By 2016, homophobia in Indonesia heightened to a point where there was a moral panic about nonheteronormative gender and sexualities, and politicians started to speak of a legal change that would make homosexuality and transgenderism illegal. Hotels and bars were raided on a daily basis, and anyone suspected of engaging in 'immoral' acts was taken to the police station. If arrested in a province with bylaws against immorality, they were charged. In January that year, the Indonesian Minister of Higher Education, Research and Technology Muhammad Nasir said that the community of lesbian, gay, bisexual and transgender (LGBT) people should be barred from universities because they violated Indonesia's moral values. ${ }^{9}$ Following the minister's statement, many universities, including the national symbol of resistance, the University of Indonesia (UI), openly banned organizations of LGBTs from doing activities on their campuses. UI, for instance, officially announced that the LGBT support center, named the Support Group and Resource Center on Sexuality Studies (SGRC), had no permit and could not operate on the campus. ${ }^{10}$

On a related point, the so-called moral panics have not been limited to antiLGBT responses. There have been other panics about sexuality across Indonesia, for instance, in post-1998 Indonesia, more 'mainstream' moral panics had to do with premarital sexual

9 The Jakarta Post reported the minister's statement on January 25, see https://www.thejakartapost.com/news/2016/01/25/lgbt-not-welcomeuniversity-minister.html (accessed on 4 December 2020).

10 Beside reporting the minister's statement that he had told all campuses to ban LGBT community, Indonesia's biggest online news portal Detik.com also include official statement from the University of Indonesia on the matter, see: (Batubara 2016). 
activity and drugs. This created panic among parents, who in turn supported the narratives and actions of conservative groups and helped strengthened the groups' standing as defenders of Islamic morality in the country.

\subsection{The Antipornography Law and Its Discontents: Repressing Sexuality, Creativity}

The passage of the antipornography bill (Rancangan Undang Undang Anti Pornografi dan Pornoaksi) into law in 2008 was seen as a victory for conservative groups in Indonesia, given that the law appears to be an embodiment of all the teachings and agenda that this lobby had been promoting since the fall of Suharto. Specifically, they succeeded in inserting into the national legal system Islamic conservative definitions of morality and sexuality while framing women and the family within a restrictive ambit. With this, conservative Islam's treatment of sexuality entered the public realm with real consequences on the people.

The bill divided the nation into two camps, with conservative groups agitating for its adoption, while liberal and moderate Muslims protested and called for it to be scrapped. On the pretext that Indonesians were in danger of being taken over by Western culture and freely circulating pornography (in the form of illegal DVDs), as well as dangdut erotic dances and erotic publications ${ }^{11}$, the Islamic party, PKS, supported by then-president Susilo Bambang Yudhoyono's Democratic Party (Partai Demokrat) and other Islamic parties, led efforts in the House of Representatives. Conservative organisations promoted the bill. Other groups, such as the FPI and MUI, which issued a fatwa (religious edict), endorsed the immediate passage of the bill by promoting it outside parliament, including the mobilisation of public rallies.

The liberal-moderate Muslim camp-which comprised human rights groups and activists, artists, art workers, women's organisations, media such as the English-language Jakarta Post, a segment of NU including former president Abdurrahman 'Gus Dur' Wahid and his wife Sinta Nuriyah, and the nationalist Partai Demokrasi Indonesia-Perjuangan (PDI-P, Indonesian Democratic Party of Struggle)—strongly rejected the bill and managed to delay its passage, including getting it revised twice (Allen 2007).

At the centre of the contestation was the short-lived magazine Playboy Indonesia, cited as a major reason why the country needed an antipornography law. This was despite the fact that none of the issues produced in Indonesia contained nudity, as would be true of Playboy magazines elsewhere in the world. The publication's forced closure earlier in 2006 had already shown the arbitrary exercise of Islamic conservative power when those such as the then-vice president Jusuf Kalla openly rejected the publication, saying that Indonesia was not America (Detik.com, 27 January 2006). Having shut it down, the Islamic group, FPI, also initiated legal proceedings against its chief editor Erwin Arnada. Labelling him a "moral terrorist", FPI criticised the authorities when Erwin initially fled and could not be found. ${ }^{12}$ Human rights activists correctly pointed out that this trial "highlighted the growing power of Islamist groups" (BBC News, 23 June 2013).

Following heated debates in Parliament, a watered-down version of the bill was passed into law in October 2008. This appeared inevitable given that it had the backing of large Islamic organisations like Muhammadiyah and then-President Susilo Bambang Yudhoyono, who was seeking re-election in the 2009 presidential elections. The controversy surrounding the law, however, continued even after its passage, when a group of human rights activists filed a petition with the Constitutional Court. This was later rejected (Indonesian Constitutional Court's decision No. 10/2009).

The most contentious part of this law is its definition of pornography (article 1). This covers any sexual material in the form of pictures, sketches, illustrations, photographs, writings, voice, sound, moving pictures, animation, cartoons, poetry, conversations, movements

11 Tempo magazine published an investigative story on these tabloids and magazines in its 13 February 2006 edition, see: https://majalah.tempo.co/ $\mathrm{read} / \mathrm{kriminalitas} / 118132$ / setelah-ibu-negara-meradang (accessed on 5 December 2020).

12 He was subsequently arrested on the island of Bali and jailed for ignoring orders to surrender after he had been sentenced to two years imprisonment for indecency in August 2010. However, the Supreme Court acquitted him the following year. 
of the body, or any other form shared through a variety of communication media and/or performances in public, and which contain obscenities (kecabulan) or sexual exploitation that violate moral norms (kesusilaan).

It imposes harsh penalties on offenders. Anyone caught "displaying nudity" in public, for instance, could spend up to 10 years in prison and be fined up to USD 500,000. Downloading pornography from the internet can result in a maximum jail sentence of four years. The law that personifies the imagination of sexuality and sexual behaviour held by Islamic conservative groups is problematic on many other grounds.

First, it is based on morality according to teachings of religion. This can be seen in its explanatory section, which states that one of its objectives is "to uphold moral values that originate from religion" and in article 3(c), which spells out its aim "to provide moral education for society." (Indonesia's Law No. 44/2008) It is also clear that religion here refers to Islam and the said morality is Islamic morality based on the interpretation of the conservative lobby.

Second, the law has an overarching definition of pornography that can punish all activities regarded as violating morality. At the same time, this definition is ambiguous and has room for different interpretations. For instance, how does one decide if an act is obscene? What does "sexual exploitation" mean? What moral norms should be followed? Morality is a matter of individual experience and belief, and there may not be a common understanding of its meaning. Despite this, the law imposes a homogeneous view of morality and a set of norms that everyone is expected to follow.

Third, with its lack of clarity and ambiguity, the antipornography law can be used against anyone who does not conform to conservative Muslim interpretations of culturally acceptable dress codes and behaviour in public and private, as well as artistic expressions and educational literature. It can also be used to single out people who do not conform to notions of 'authentic' Indonesian values. The different views and treatment of what is considered to be impolite, immoral, or pornographic from various religious, ethical, and regional and cultural streams in Indonesia render the law highly controversial.

Fourth, the law is patriarchal and discriminates against women by singling them out as weak and in need of protection. ${ }^{13}$ As lawmakers imagined women as the sexual objects of pornography, they likely thought it beneficial to control women so that they do not to go out often or late at night or dress and behave in ways that would arouse men's desire and thus, invite rape.

Fifth, women bear the brunt of punitive actions since they are blamed for arousing men's desire. A recent case involving the leaked sex tape of singer Gissela Anastasia illustrates this point, of the law criminalising women rather than protecting them. Despite the fact that her cellular phone containing the video was stolen and that she had no knowledge about the video being circulated and watched by millions of people on the Internet, she was named as a suspect in the case. She faces up to 10 years in jail if convicted (Detik.com, 2 March 2021).

Sixth, the antipornography law has encouraged vigilantism, unlawful raids, and censorship. Hundreds of clubs, bars, and amusement centres have been raided, with thousands arrested under the law. ${ }^{14}$ Such raids take place almost every week. On 29 August 2020, police forcibly broke up a party at a hotel, arrested nine men alleged to be homosexuals and charged them with the crime of "facilitating obscene acts", hence discriminating against LGBT people (Antaranews.com, 3 September 2020).

Seventh, the LGBT community is also targeted under this law. In January 2020, the mayor of Depok, a city in West Java, ordered police to raid private residences to look for "immoral acts" and "prevent the spread of LGBT". Earlier in January 2018, the police in Cianjur, a West Java province, raided a gathering of five men in a private home. Citing the antipornography law, the police told reporters the men were caught at a "sex party" and

13 For details, see point 3 under the general section of the Anti-Pornography Law.

14 All data about raids are taken from a report by the Human Rights Watch, see, for instance: https://www.hrw.org/news/2020/09/07/indonesiainvestigate-police-raid-gay-party (accessed on 5 December 2020). 
showed condoms and lubricant as evidence. In May 2017, the Jakarta police, helped by members of militant groups, raided the Atlantis gym and sauna. They arrested 141 people, most of whom were reportedly gay or bisexual men. Ten of them were prosecuted under the antipornography law. In fact, in 2017 alone, the police apprehended at least 300 LGBTs, a spike from previous years and the highest such number ever recorded in Indonesia (Nikkei, 19 February 2018).

Eighth, the creativity of the nation's artists and others has suffered as well. The law has instilled fear in artists, journalists, and others working in the creative industry and limits their freedom of expression. They are forced to restrain themselves and, in many cases, practise self-censorship instead of freely creating content. This has raised concerns about the quality of their work being compromised.

\subsection{The Impact of Islamic Conservatism on Popular Culture: The Inul 'Drill Dance' Controversy}

Prior to the national debate on the pornography bill, there was an incident that would go on to shape the course of Indonesia's cultural landscape in the following years. This involved dangdut singer Inul Daratista. In 2003, the East Javanese singer not only became the talk of the nation with her erotic 'goyang ngebor' ('drill dance')—-making rapid circular movements with her hips mimicking the actions of a drill to the infectious beat of dangdut music - but was also a global phenomenon. From The New York Times and the Wall Street Journal to the BBC, The Guardian, and many other local and international publications, her story made headlines and, overnight, dangdut music turned into an international sensation. ${ }^{15}$

It did not take long for MUI to issue a fatwa declaring Inul's dance "pornographic". Others followed suit in condemning her. Indonesia's 'King of Dangdut' Rhoma Irama, a legendary dangdut singer-songwriter, said that her dance was a "threat to the nation's morality" (Sulistiono 2003). He then forbade her from performing his songs in all her stage shows. The MMI, a coalition of Islamic groups centred in Yogyakarta, protested a television show that she appeared in, Duet Maut (Deadly Duet), stating that the show encouraged premarital sex and excited men to commit immoral acts (Weintraub 2008).

These public statements ignited a huge debate in popular print media. Weintraub (2008) reports that "Politicians, religious leaders, feminists, intellectuals, celebrities, fans, and even doctors, who warned female fans not to try the dangerous drilling move at home without proper warm-up," all weighed in to have their say. Human rights activists and liberal groups spoke out in her defence, as did several high-profile figures, such as Gus Dur, the highly regarded Islamic poet Emha Ainun Najib, as well as Taufiq Kiemas, husband of then-president Megawati Soekarnoputri. With such strong backing, Inul and her 'drill dance' legacy survived, a small victory for the freedom of expression in an increasingly conservative country.

Since then there have been dozens of studies and many articles on the Inul phenomenon, ranging from questions around power, gender, and sexuality, to feminism and woman's rights, as well as morality and freedom of expression. Weintraub (2008), for instance, concluded that Inul's dance grew into a focal point for public debates about religious authority, freedom of expression, women's rights, and the future of Indonesia's political leadership. This article does not delve into such analysis as it is clear that even without evidence, Islamic conservative groups successfully asserted their moral values onto Inul by declaring that her dance led to immorality and premarital sexual relations.

What is more important for Indonesia-for its popular culture and the nation's future as a whole-was the missed opportunity involved. Rather than being dragged into endless and pointless discussions about sexuality and religious morality, and killing the nation's creativity in the process, Indonesia could have capitalised on the moment that global attention was focused on dangdut. This is even more so since it has long searched for a

15 For The Guardian, see (Nakashima 2003).For the Wall Street Journal see (Mapes 2003), for The New York Times, see Julia Suryakusuma's piece (Suryakusuma 2003). 
global brand to thrust itself into the limelight. Dangdut and dangdut singers like Inul have all the ingredients to reach the fame of Korean boy and girl K-pop bands. Dangdut with its beat, rhythm, and singer has proven its powers to hypnotise the masses. No one can sing dangdut like Indonesian dangdut singers, and no one can dance like Inul, not even the Koreans. All that was needed for it to take off was some awareness and support. Instead, Indonesians were lectured on morality and how women had to be sexually restrained and remain at home.

\section{Conclusions}

The social experimentation of pushing Indonesia into adopting an Islamic conservative definition of sexuality and morality was antidemocratic and violates the rights of many sections of the population. It is hard to understand how a nation with as many ethnic groups, cultures, and religions as Indonesia ended up going in this direction after freeing itself from authoritarian rule in 1998. Few expected that a small but loud and powerful group of people with selectively narrow interpretations of the Qur'an and Hadith would be successful in hijacking the national trajectory and steering it towards the path of Islamic conservatism.

These are people who operate by asserting their beliefs-that is, without providing proof to back their claims-that upholding a selectively narrow Islamic definition of sexuality and morality will improve the overall wellbeing of a society. While the goal of fostering a morally upright population has always been cited as the reason for promoting this version of Islam, the push by Islamic hardliners has little to do with morality. Instead, it has everything to do with power accumulation, domination, and control.

The foregoing account demonstrates how post-totalitarian-era Indonesia has become very divided due to the imposition of a narrow and particular conception of morality on a very heterogeneous nation. In any controversy-from Inul Daratista's 'drill dance' and the closure of Playboy Indonesia to the debates around the antipornography bill and contests to define sexuality and morality - the nation was sown with hatred and forced to choose sides. Today, sexuality, having been defined with the admittance of intimacy into the public sphere, has been utilized to control the unruly body associated with pornography, homosexuality, and immorality, from their broad to their arbitrary senses. Whenever a political group or even state actors need to scapegoat an 'unacceptable' individual or another group, this 'weapon' of body destruction has been effectively deployed.

One grave danger of such an arbitrary and limited definition of sexuality for an emerging nation like Indonesia is that it destroys creativity, a valuable currency for countries to survive and prosper in this era. Indonesia could have made dangdut its global brand, comparable to rock music, K-pop, or Bollywood dancing. Instead this music and dance genre was discredited as promoting premarital sex relations and pornography. Ironically, many Indonesians, even women with long hijab, have continued to enjoy such 'nonIslamic' form of entertainment today.

Funding: This research received no external funding.

Institutional Review Board Statement: Not applicable.

Informed Consent Statement: Not applicable.

Conflicts of Interest: I have no conflict of interest in writing this article.

\section{References}

\section{Archival Sources}

'Jusuf Kalla Tolak Playboy'. 2006. Detik.com, January 27. Available online: https://news.detik.com/berita/d-527707/jusuf-kalla-tolakplayboy (accessed on 5 December 2020).

'LGBT not welcome at university: Minister'. 2016. Jakarta Post, January 25. Available online: https:/ /www.thejakartapost.com/news / 2016/01/25/lgbt-not-welcome-university-minister.html (accessed on 5 December 2020). 
'Polisi selidiki komunitas homo usai gerebek pesta asusila di Jakarta'. 2020. Antaranews.com, September 3. Available online: https://www.antaranews.com/berita/1705782/polisi-selidiki-komunitas-homo-usai-gerebek-pesta-asusila-di-jaksel (accessed on 5 December 2020).

Undang-Undang Republik Indonesia No. 44 tahun 2008 tentang Pornografi (document of the 2008 Antipornography Law). Available online: https:/ / www.dpr.go.id/dokjdih/document/uu/UU_2008_44.pdf (accessed on 20 December 2020).

'Setelah Ibu Negara Meradang'. 2006. Majalah Tempo, February 13. Available online: https:/ / majalah.tempo.co/read/kriminalitas/11 8132/ setelah-ibu-negara-meradang (accessed on 5 December 2020).

\section{Published Sources}

Adjie, Moch Fiqih Prawira. 2020. Survey on acceptance in Indonesia gives LGBT community hope. Jakarta Post. June 29. Available online: https: / www.thejakartapost.com/paper/2020/06/28/survey-on-acceptance-in-indonesia-gives-lgbt-community-hope. html (accessed on 2 April 2021).

Allen, Pam. 2007. Challenging Diversity?: Indonesia's Anti-Pornography Bill. Asian Studies Review 31: 101-15. [CrossRef]

Batubara, Herianto. 2016. Menristek: Saya Larang LGBT di Semua Kampus, Itu Tak Sesuai Nilai Kesusilaan! Detik.com. January 24. Available online: https:/ / news.detik.com/berita/d-3125654/menristek-saya-larang-lgbt-di-semua-kampus-itu-tak-sesuai-nilaikesusilaan (accessed on 9 December 2020).

Beech, Hannah, and Muktita Suhartono. 2019. Faith Politics on the Rise as Indonesian Islam Takes a Hard-Line Path. New York Times. April 15. Available online: https://www.nytimes.com/2019/04/15/world/asia/indonesia-election-islam.html (accessed on 20 November 2020).

Brenner, Suzanne. 2011. Private Moralities in the Public Sphere: Democratization, Islam, and Gender in Indonesia. American Anthropologist 113: 478-90. [CrossRef]

Cahya, Gemma Holliani. 2021. 'We live here': Fears tourist tweets on gay lifestyle may backfire on Bali's LGBT community. The Guardian. January 27. Available online: https://www.theguardian.com/world/2021/jan/27/bali-us-tourist-tweets-gay-lgbtlifestyle-community-indonesia (accessed on 5 February 2021).

Davies, Sharyn Graham. 2019. Islamic Identity and Sexuality in Indonesia. In The Palgrave Handbook of Ethnicity. Singapore: Springer, pp. 1063-76.

Dialmy, Abdessamad. 2010. Sexuality and Islam. The European Journal of Contraception and Reproductive Health Care 15: 160-68. [CrossRef] [PubMed]

Erdianto, Kristian. 2016. HRW: Pernyataan Pejabat Negara Membuat LGBT Indonesia di Bawah Ancaman. Kompas.com. August 11. Available online: https:/ / nasional.kompas.com/read/2016/08/11/20071441/hrw.pernyataan.pejabat.negara.membuat.lgbt. indonesia.di.bawah.ancaman?page=all (accessed on 3 December 2020).

Farisa, Fitria Chusna. 2019. Ini Hasil Lengkap Pemilu Legislatif 2019 yang Ditetapkan KPU. Kompas.com. May 21. Available online: https: //nasional.kompas.com/read/2019/05/21/05000061/ini-hasil-lengkap-pemilu-legislatif-2019-yang-ditetapkan-kpu (accessed on 2 April 2021).

Fealy, Greg. 2018. Nahdlatul Ulama and the Politics Trap. New Mandala. Available online: https://www.newmandala.org/nahdlatululama-politics-trap/ (accessed on 6 December 2020).

Human Right Watch. 2018. "Scared in Public and Now No Privacy": Human Rights and Public Health Impacts of Indonesia's Anti-LGBT Moral Panic'. July Special Report. Available online: https://www.hrw.org/report/2018/07/01/scared-public-andnow-no-privacy/human-rights-and-public-health-impacts (accessed on 5 December 2020).

Jibiki, Koya. 2020. Indonesia's 75th anniversary highlights rise of political Islam. Nikkei. August 18. Available online: https: / / asia.nikkei.com/Politics/Indonesia-s-75th-anniversary-highlights-rise-of-political-Islam (accessed on 10 December 2020).

Mapes, Timothy. 2003. Ms. Inul's ‘Drill' Shakes Up Indonesia's Muslim Culture. The Wall Street Journal. July 21. Available online: https:/ / www.wsj.com/articles/SB105872604979566600 (accessed on 26 November 2020).

Nakashima, Ellen. 2003. Why a 'dirty' dangdut dancer has Indonesia's clerics in a twist. The Guardian. June 12. Available online: https:/ / www.theguardian.com/theguardian/2003/jun/12/guardianweekly.guardianweekly1 (accessed on 26 November 2020).

Paddock, Richard C. 2021. American Woman Deported from Bali After Calling It ‘Queer Friendly. New York Times. January 20. Available online: https: / / www.nytimes.com/2021/01/20/world/asia/kristen-gray-bali-deported.html (accessed on 10 February 2021).

Platt, Maria, Sharyn Graham Davies, and Linda Rae Bennett. 2018. Contestation of Gender, Sexuality and Morality in Contemporary Indonesia. Asian Study Review 42: 1-15. [CrossRef]

Qibtiyah, Alimatul. 2019. Hijab di Indonesia: Sejarah dan kontroversinya. The Conversation. February 22. Available online: https:/ / theconversation.com/hijab-di-indonesia-sejarah-dan-kontroversinya-112029 (accessed on 15 February 2020).

Sani, Ahmad Faiz Ibnu. 2018. Survei SMRC: 87,6 Persen Masyarakat Menilai LGBT Ancaman. Tempo. January 25. Available online: https:/ / nasional.tempo.co/read/1053909/survei-smrc-876-persen-masyarakat-menilai-lgbt-ancaman (accessed on 2 April 2021).

Sebastian, Leonard C., Syafiq Hasyim, and Alexander R. Arifianto, eds. 2021. Rising Islamic Conservatism in Indonesia: Islamic Groups and Identity Politics. New York: Routledge. 
Setara Institute for Democracy and Peace. 2019. Freedom of Faith and Religious Condition in Indonesia. November 10. Available online: https:/ / drive.google.com/file/d/18GIKLonGcWDzQ0hC_yzXfPhr7KGkIc9s/view (accessed on 30 November 2020).

Sulistiono. 2003. Inul Vs Rhoma dalam Perspektif UU Hak Cipta. Hukumonline. June 15. Available online: https://www.hukumonline. com/berita/baca/hol8170/inul-vs-rhoma-dalam-perspektif-uu-hak-cipta/ (accessed on 26 November 2020).

Suroyo, Gayatri, and Tabita Diela. 2019. Ground shifts in Indonesia's economy as conservative Islam takes root. Reuters. August 28. Available online: https://www.reuters.com/article/us-indonesia-economy-islam-insight-idUSKCN1VI09F (accessed on 1 December 2020).

Suryakusuma, Julia. 2003. A singer's gyrating rattles Indonesia. New York Times. May 14. Available online: https://www.nytimes. com/2003/05/14/opinion/IHT-meanwhile-a-singers-gyrating-rattles-indonesia.html (accessed on 26 November 2020).

The World Population Review. 2021. Muslim Population by Country. Available online: https://worldpopulationreview.com/countryrankings/muslim-population-by-country (accessed on 20 November 2020).

Weintraub, Andrew N. 2008. "Dance Drills, Faith Spills": Islam, Body Politics, and Popular Music in post-Suharto Indonesia. Popular Music 27: 367-92. [CrossRef]

Wieringa, Saskia E. 2015. Gender Harmony and the Happy Family: Islam, Gender and Sexuality in Post-Reformasi Indonesia. South East Asia Research 23: 27-44. [CrossRef]

World Health Organization. 2002. Defining Sexual Health: Report of a Technical Consultation on Sexual Health. Geneva: World Health Organization, January 28-31. Available online: https://www.who.int/reproductivehealth/publications/sexual_health/defining_ sexual_health.pdf (accessed on 25 November 2020).

Yip, Andrew Kam-Tuck. 2009. Islam and Sexuality: Orthodoxy and Contestation: Editorial Introduction. Springer Sciences + Business Media B.V., February 12. 